\title{
Development of Didactic Culture for Educational Cooperation in Eurasia
}

\author{
Marina P. Tyrina \\ Altai State University \\ Ludmila G. Kulikova \\ Altai State Pedagogical University
}

In the paper, we analyze the research on didactic culture conducted in the world. Within the study, we aim to create the didactic culture theory as a methodological platform for expanding educational cooperation in Eurasia. In particular, we consider the definitions of the conceptual content of didactic culture and compare the approaches to identifying its functions, subjects, and types. Furthermore, we differentiate didactic culture and didactic competence and present various points of view on the stages, technologies, conditions, and means of forming the didactic culture of a teacher, educational organization, pedagogical community, and society. Within the dominant orientation to implementing the competence approach in education, the scientific novelty of the research is appealing to the didactic culture as a condition for expanding the Eurasian educational cooperation. When writing the paper, we use a comparative method of analyzing research materials in chronological order.

Keywords: didactic culture, professional pedagogical culture, didactic competence

\section{INTRODUCTION}

Developing and expanding educational cooperation in Eurasia requires establishing a unified didactic culture of educational systems in the participating countries. The study of didactic culture meets the challenges of globalization and modernization in education. Developing this thesis requires considering the leading directions of international cooperation in education. For example, in Japan, cooperation is implemented in the following ways: (1) through collaborative, contractual, and cooperative research; (2) by receiving and using donations for research; (3) via research programs conducted with the help of grants provided by the Ministry of Education, Science, and Culture. The main forms of educational cooperation in Europe are joint centers, techno-parks (technopolises), and science parks.

The generalized experience of this work can serve as the foundation for building conceptual models of university centers and cooperative research. Joint projects are a common form of educational cooperation in Germany. There is contact between universities in different countries, research organizations, industries, consulting centers, and services regarding innovative activities.

The increasing requirements for universal culture and special training level of graduates explains the need to develop didactic culture (Sinchishina, 2010). An argument is a change of educational paradigms that fix the transition from mass reproductive forms and teaching methods to individual creative ones. The 
relevance of increasing didactic culture level among teachers is associated with changes in the sociocultural environment of higher education (Tsokur, 2010).

Low didactic culture is the reason for the lack of practical application of individualized, problem-based, group, and programmed learning (Vilotievich, 2003). Developing the didactic culture is recognized as a significant component of educational strategy and tactics (Samodrin, 2006). Some authors emphasize that it is necessary to create high-quality educational and methodological complexes (Krasnova \& Egorova, 2009). Didactic and research culture is proclaimed a universal personal characteristic of a modern specialist in education (Tsokur, 2010). It encourages a student at a pedagogical university to self-development and creativity (Grinjov, 2002). Didactic culture contributes to creating and developing new pedagogical values and technologies by teachers, self-development of their personality, and didactic cultural creativity (Klachko \& Plaksin, 2009). Didactic culture ensures the productivity of learning activities and creative selfrealization (Morozov \& Sinchishina, 2009; Sinchishina, 2010). Didactic culture regulates activities, communication, and behavior of the process participants (Tsokur, 2010).

For establishing didactic culture as a methodological basis for developing Eurasian educational cooperation, it is essential to agree on common approaches to the content of this concept, its functions, subjects, types, and differences from didactic competence. It is important to analyze and promote productive technologies, conditions, and means of forming the didactic culture of a teacher, educational organization, pedagogical community, and society.

\section{MATERIALS AND METHODS}

The paper analyzes the research of didactic culture conducted in the world. During the analysis of works on didactic culture, we look for answers to the following research questions:

- What the functions of didactic culture are;

- What the difference is between didactic culture and didactic competence in understanding these concepts by scholars;

- Who or what the subject of didactic culture is;

- What the main types of didactic culture are;

- What stages the process of forming the didactic culture includes;

- What technologies the authors offer to develop the didactic culture of a teacher;

- What conditions the researchers consider necessary for forming the didactic culture;

- What means can be used for developing this type of pedagogical culture.

The answers to these questions help us to summarize the theoretical foundations for developing the didactic culture as a methodological platform for expanding educational cooperation in Eurasia.

Within the study, we use a chronological comparative method to analyze the research materials. We have analyzed dissertations, monographs, and articles in chronological order, which allows us to identify the genesis of pedagogical knowledge and indicate its growth points. The chronological comparative method applied universally refers to general scientific research methods. Consequently, this fact allows us to apply this method for solving the existing research problems.

\section{RESULTS}

When developing the didactic culture theory as a methodological platform for expanding educational cooperation in Eurasia, we have not identified its comprehensive research in English. Nevertheless, we have found that the term didactic culture is widely used. Thus, many researchers discussed changes in university didactic culture with the involvement of this term. At the International Congress for Mathematics Education, this term helped describe the typical ways for teacher-student interaction in teaching mathematics (Clanche \& Sarrazy, 2006). S. Prediger, M. Bosch, I. Kidron, J. Monaghan, and G. Sensevy (2009) also identified the current issues of mathematical education. 
Ukrainian researchers actively use the term didactic culture. It is indicative that didactic culture is of particular interest to the teachers of higher military educational institutions of Ukraine. We have also found this term in the research of the Yugoslav educator M. Vilotievich (2003) and Belarusian colleagues T. I. Krasnova and Yu. N. Egorova (2009).

We have not found comprehensive studies of didactic culture in world pedagogy. V. Grinjov (2002) and O. A. Sinchishina (2010) conducted the most profound studies of this type of pedagogical culture. They followed the cultural traditions of Russian pedagogy (Bondarevskaya, 2010; Slastenin, Isaev \& Shiyanov, 2002).

Foreign writers discuss didactic culture. M. Eliade, the representative of avant-garde Romanian literature, recognized the timeliness of this term. Unfortunately, it did not reveal the essence of didactic culture (Eliade, 1996). D. Fowles, the classic of English literature, contrasted the didactic morality of the $19^{\text {th }}$ century with the didactic culture of the $20^{\text {th }}$ century (and not in favor of the latter). The author revealed the possible progressive and regressive development of didactic culture in society (Fowles, 2003).

The role of didactic culture in developing educational cooperation also proves that the subject list of didactic culture is gradually expanding. A. Tsokur (2010), and M. Tyrina and L. Kulikova (2019) study the didactic culture of a university teacher. V. Klachko \& A. Plaksin (2009), U. V. Balashova (2010), and O. A. Sinchishina (2010) have written much about the didactic culture of a military university teacher. B. V. Avramenko (2011) studied the process of forming the didactic culture of academic and teaching staff training in candidate's programs. Russian researchers did not do that. V. Grinjov (2002) studied the process of forming the didactic culture among students of higher pedagogical educational institutions. In the research of N. A. Savchuk (2005), teachers at Ukrainian secondary schools were the subject of didactic culture. O. Semenog (2003) wrote a textbook on the ethnolinguistic and didactic culture of language and literature teachers.

For our research subject, differentiating the didactic culture of society and an individual is of particular interest. For example, D. Fowles (2003) wrote about objective (collective) rather than subjective (individual) didactic culture. At the same time, he wrote about the possible progressive and regressive development in the didactic culture of society. Besides, the requirements for the didactic culture of the profession-oriented school were formulated.

Basing educational cooperation on the developed didactic culture of interaction subjects necessitates determining the content of the key concept. Didactic culture is "integrated personal education, which determines the effectiveness of educational and cognitive activities of training subjects, contributes to the creation and development of pedagogical values and technologies by students, and encourages them to selfdevelopment and creativity" (Grinjov, 2002). This term implies "an integral property of the personality of a teacher, which provides an effective pedagogical activity for forming the professional culture of a future specialist and contributes to the creation and development of new pedagogical values and technologies by a teacher, self-development of his/her personality and the creation of didactic culture" (Klachko et al, 2009). Didactic culture is "an integral quality of personality represented by the unity of motivational and axiological, innovative and technological, and personal and creative components that ensure productive didactic activity and creative self-realization of a teacher" (Sinchishina, 2010). There is one more definition. Didactic culture is "a measure of the achieved development of a university teacher, his/her inner world, professional and pedagogical potential, and readiness for a variety of educational activities based on preserving and disseminating the world of didactic values" (Tsokur, 2010).

The essence of any object primarily reflects its structure. A. Tsokur (2010) described the structure of didactic culture as a synthesis of cognitive, technological, axiological, and subjective components. Didactic culture is structured into modules, which consist of components and system-forming elements. There are personal-motivational, didactic-competence, and analytical-reflexive modules (Grinjov, 2002). It is essential for us that $\mathrm{V}$. Grinjov brought didactic competence to the structure of didactic culture. V. Klachko and A. Plaksin (2009) shared the same opinion.

The researchers did not sufficiently examine the formation and development of the didactic culture in foreign pedagogy, unlike Russian. The results of two or three studies are not sufficient for the qualitative 
design of an integral and continuous process of developing the didactic culture of a specialist (Sinchishina, 2010; Grinjov, 2002).

The functions of developing the didactic culture of a teacher are imposed on various system parts for improving pedagogical skills: institutes of professional development, methodological associations, and organizations for retraining teaching staff. Pedagogical universities lead to forming didactic culture (Grinjov, 2002). Some foreign researchers include master's and candidate's programs into this process. However, they do not describe the mechanisms of networking interaction of all subjects.

O. Sinchishina (2010) suggested a specific model for forming didactic culture. This model includes basic-fundamental, perspective-predictive, and activity-effective functional blocks. U. V. Balashova (2010) described some forms for increasing didactic culture. A. Tsokur (2010) believed that the didactic culture of a university teacher is acquired during special professional training (general pedagogical and scientific) within master's and candidate's programs.

Some studies describe certain conditions for forming modern didactic culture. They include the following: (1) activation of the internal professional motivation of teachers; (2) combination of innovative and traditional forms of education; (3) subject-subject interaction in a pedagogical system; (4) coherence of technology for developing didactic culture; (5) consideration of the specifics of the disciplines taught and individual characteristics of teachers and students; (6) activation of the internal professional motivation of teachers; and (7) systematic analysis and correction of the results in didactic activities of teachers (Sinchishina, 2010; Tyrina, Kulikova \& Fazilbekov, 2019).

\section{DISCUSSION}

As we can see, psychological and pedagogical studies contain specific theoretical prerequisites for forming the didactic culture as a methodological basis for expanding Eurasian educational cooperation.

We can see the functional purpose of didactic culture in the context of changing educational paradigms in sociocultural and educational environments. Didactic culture affects the depth of implementing innovative technologies in educational practice. It also becomes a necessary characteristic of educational organizations and subjects of the pedagogical process. It is a repository of traditional pedagogical values and an initiator of new ones. Didactic culture is recognized as a regulator of didactic activities.

The researchers of Ukraine, Belarus, and Yugoslavia have been studying didactic culture. Russian cultural traditions influence the research results in these countries. The subject list of this type of pedagogical culture is gradually expanding - from a university teacher to an officer. For the topic under the study, society, educational organizations, and separate pedagogical systems must be the bearer of didactic culture.

Didactic culture is recognized as an integrated personal formation, an integral property or quality of an individual, and a measure of the development achieved by a teacher. Its structure includes motivational and axiological, innovative and technological, and personal and creative components. They are also called motivational, didactic, competence-based, and analytical-reflective ones. Despite the various approaches, cognitive, technological, axiological, and subjective components are outlined in didactic culture.

Within the competence approach prevailing in education, the question of the relationship between didactic competence and didactic culture remains unresolved and has all possible options as an answer: (1) didactic culture is already recognized as didactic competence; (2) didactic culture is understood more broadly than didactic competence; and (3) didactic culture is called identical to didactic competence.

The researchers have not sufficiently studied the formation and development of the didactic culture in foreign pedagogy. The design of an integral succession process for the development of the didactic culture of a teacher in the system of continuous professional education has not been fully implemented yet. The mechanisms of networking interaction of organizations that develop the didactic culture of teaching staff need a description. We need new promising technologies for forming didactic culture. The segmental conditions for developing this type of pedagogical culture require their systematization. The educational and methodological base is expecting specific scientific and practical recommendations for developing the didactic culture. 


\section{CONCLUSION}

Thus, the analysis of leading directions and the research results of the didactic culture of a teacher gave grounds for recognizing didactic culture as a possible basis for expanding and developing Eurasian educational cooperation. In its didactic manifestation, the culture will be able to unite the efforts of progressive scientists and practitioners for developing education in the $21^{\text {st }}$ century within cultural-creative pedagogical models and cultural-contextual educational paradigms influenced by the principle of cultural conformity.

\section{REFERENCES}

Avramenko, B.V. (2011). Forming the didactic culture of future scientific and pedagogical personnel within the candidate's program [Dissertation of Candidate of Pedagogical Sciences]. Odesa, Ukraine: Ternopil Volodymyr Hnatiuk National Pedagogical University.

Balashova, U.V. (2010). Didactic culture of higher military personnel as a pedagogical problem. Khmelnytsky, Ukraine: National Academy of the State Border Guard Service of Ukraine named after B. Khmelnytsky.

Bondarevskaya, A.I. (2010). Cultural and educational space of the university as an environment for the professional and personal self-development of students. Rostov-on-Don, Russia: Bulat.

Clanche, P., \& Sarrazy, B. (2006). Occurrence of typical cultural behavior in an arithmetic lesson: How to cope? In M. Niss (Ed.), Proceedings from: 10th International Congress of Mathematics Education: Ethnomathematics and Mathematics Education (pp. 1-9). Copenhagen, Denmark: Roskilde University.

Eliade, M. (1996). Myths, dreams, mysteries. Moscow, Russia: Wakler.

Fowles, D. (2003). Aristos. Moscow, Russia: Symposium.

Grinjov, V. (2002). Forming the didactic culture of a future teacher [Dissertation of Candidate of Pedagogical Sciences]. Kharkiv, Ukraine: Kharkiv State Pedagogical University.

Klachko, V., \& Plaksin, A. (2009). Didactic culture of a teacher at a higher educational institution of the Ministry of Internal Affairs in psychological and pedagogical research: A problematic aspect. Bulletin of the Academy of Management of the Ministry of Internal Affairs, 2, 164-174.

Krasnova, T.I., \& Egorova, Yu. N. (2009). Difficulties teachers have when developing teaching materials. Learning Activities of a University Student: From Management to Self-Government, pp. 188-192. Minsk, Belarus: Belarusian State University.

Morozov, S., \& Sinchishina, O. (2009). Features of the methodology for determining the level of the didactic culture of a teacher of a higher military educational institution. Ternopil, Ukraine: Ternopil National Pedagogical University.

Prediger, S., Bosch, M., Kidron, I., Monaghan, J., \& Sensevy, G. (2009). Different theoretical perspectives and approaches in mathematics education research - Strategies and difficulties when connecting theories. Retrieved from http://www.mathematik.unidortmund.de/ prediger/veroeff/10-CERME-WG9-2009-Introduction.pdf

Samodrin, A.P. (2006). Formation of training and educational space in the region. Kremenchuk, Ukraine: PP Shcherbatykh.

Savchuk, N.A. (2005). Psychological and pedagogical conditions for correcting personal disharmony among teachers of general schools [Dissertation for the Degree of Candidate of Psychological Sciences]. Minsk, Ukraine: G.S. Kostiuk Institute of Psychology of the National Academy of Educational Sciences of Ukraine.

Semenog, O. (2003). Ethnolinguistic and didactic culture of a language and literature teacher. Kiev, Ukraine: Dovira.

Sinchishina, O.A. (2010). Forming the didactic culture of teachers at higher military educational institutions [Dissertation of Candidate of Pedagogical Sciences]. Khmelnitsky, Ukraine: Khmelnitsky State Pedagogical University. 
Slastenin, V.A., Isaev, I.F., \& Shiyanov, E.N. (2002). General pedagogy (Vol. 1). Moscow, Russia: VLADOS.

Tsokur, A. (2010). Toward defining the essence of the didactic and scientific research culture of a teacher of higher education. Bulletin of the National Academy of State Border Service of Ukraine Named After Bogdan Khmelnitsky, 2, 5-6.

Tyrina, M., \& Kulikova, L. (2019). Diagnosing the Results of Educator's Didactic Culture Development in the Conditions of Innovative Education. In O.M. Lyubimova (Ed.), Proceedings from ICEDER 2019: International Scientific and Practical Conference on Education, Health, and Human Wellbeing. Barnaul, Russia: Atlantis Press.

Tyrina, M., Kulikova, L., \& Fazilbekov, I. (2019). Level differentiation of the development of teacher's didactic culture in the context of innovative education. World of Science, Culture, and Education, 6(79), 385-388.

Vilotievich, M. (2003). From traditional to informational didactics. MSU Vestnik, 20(2), 83-87. 